\title{
Some Macromycetes from Yyteri sand dunes in SW-Finland
}

\author{
Paavo Kallio and Heli Heikkilä
}

Publications from the Department of Botany, University of Turku. No. 50

Only very few of the species with which ANDERsson (1950) dealt in his study of the larger fungi of sand dunes have been found in Finland. EkLund (1944, p. 213) lists Inocype lacera Fr. var. halophila from two localities in the Korppoo parish in the Turku Archipelago growing in «supralitorale sand shore». Stenlid has collected Tulostoma brumale Pers. in the sandbank, Eistrevlan in Jurmo (Korppoo) as well as in the Kökar parish (Ahvenanmaa/Åland; cf. Andersson, o.c., p. 81). One specimen in the herbarium of the University of Turku (TUR) was collected in Hummelskär, Korppoo by Ilkka Kukkonen 16.8. 1962. This fungus was not growing on sand but on the calcareous rock, amongst Tortella tortuosa (cf. also EckBLAD 1955, p. 73). One more fungus, Scleroderma bovista Fr. which according to ANDERsson (o. c. p. 70) is a southern species of sand dunes, has been mentioned by RAuTAVAara (1953) as collected from the sea shore sand dunes along the Gulf of Bothnia.

The following are some new reports of the sand dune fungi on the shore of Yyteri at the city of Pori in SW-Finland (Satakunta). The well known $\gg$ Sands of Yyteri» represents one of the largets dune districts in Finland (cf. Lemberg 1934). Only some psammophilous species form the vegetation of the area: Elymus arenarius, Festuca rubra, F. ovina, Minuartia peploides and Salix phylicifolia.

During 1960-1962 many fruiting bodies of Laccaria trullisata (Ellis.) Peck f. rugulospora Lange (LANGE 1955, p. 30) were collected by the author Heikkilä and by Mary Eriksson (TUR). The diameter of the fruiting bodies is 2-4 centimeters and corresponds to the size of the L. trullisata ssp. maritima as reported by Andersson (1950, p. 23). As a rule the foot is partially sunk in the substratum (sand) and the lower part is thicker than the upper part often with a sharp boundary between them. The surface of the foot is covered by sand grains, which are attached so firmly that the herbarium specimens after normal rinsing are still very sandy. The spores are long ellipsoid and finely punctate (Fig. 1). The size of the spores $14.6 \pm 0.07 \times 8.3 \pm 0.05$ microns - corresponds to the size reported by LANGE (12-15.5 × 7.5-8.5) but is smaller than the size for the forma maritima by Andersson (16-18 $\times 8-10$ microns).

Professor Morten Lange (Copenhagen) has kindly verified our specimens together with specimens which were collected in Greenland (LANGE 1955). The intraspecific taxa of $L$. trullisata, viz. f. maritima Teod. and f. rugulospora Lange are ecologically similar, both being sand fungi of sea shores. However, because

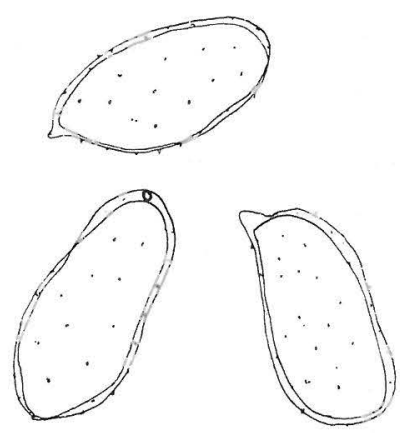

Fig. 1. Spores of Laccaria trullisata f. rugulospora.

L. laccata, a very eurotype species, is found growing in pure sea shore sand (collections e.g. from Korppoo in TUR), the habitat as such does not give many taxonomical hints. As identification of the specimens collected in the eastern shore of the Gulf of Finland by Thesleff (cf. ANDERSSON 1950, p. 25) can not be confirmed (because no specimens can be found in $\mathrm{H}$ and TUR), Yyteri is at present the only certain locality of the taxon in eastern Fennoscandia.

Inocybe lacera $\mathrm{Fr}$. var. halophila Heim. is taxonomically very close to the 1 . lacera type, but some minor 
morphological features, connected with the typical habitat characteristics, give this taxon a significance in ecological studies (Andersson o.c., p. 28). The description of Andersson of the taxon agrees with the specimens from Yyteri. The formation of »a sand dune ecotype of Inocybe lacera» (ANDERsson 1. c.) would be an appropriate resolution of the problem of this taxon. The mean value $-15.5 \times 6.4$ microns of 33 measured spores - agrees well with the size given by ANDERSSON (12-16 $\times 5.8-6.5$ microns) as well as with the values $(12-19 \times 5.5-7)$ given by KüHNER and RoMAgNesi (1953, p. 224).

Corynetes arenarius (Rostr.) Dur. This species is known from some districts in southern Scandinavia, Germany, the Netherlands, Great Britain, Greenland and in the north-eastern corner of North America (cf. Nannfeldt 1943 and Andersson o.c., Map 2). Some new localities in Sweden (kindly reported by professor J. A. Nannfeldt from Uppsala museum) can be added to the localities mapped by ANDERSSON: Skåne, Löderup 1951 (G. Malm); Norrbotten, Haparanda skärgård 1952 (Henry Kärner \& Leif Jonasson); Lycksele Lappmark, Tärna 1961 (Lennart Holm \& Erik Hesselman). The last mentioned locality is inland.

In Yyteri, the species was found in several localities in 1960-1962 together with Stereocaulon sp. and Enpetrum nigrum. Corynetes arenarius is easily identified by its polymorphous sporophores. It appears also in branched forms and often has very weakly differentiated and thick stem parts. The large size of the asci is typical for the species. The mean of 90 measurements is 124 microns but the actual sizes are between 109 and 150 microns. Hence the mean is a little higher than that mentioned by NANNFELDT (1943, p. 8). The thickness is, however, less, 9.9-13.3 microns in comparison with $12-18$ microns reported by NANNFELDT. The length of the spores varies


Fig. 2. Asci of Corynetes arenarius.

between 17 and 38 microns. The mean length is $33.3 \pm 0.3$ microns and the width $6.1 \pm 0.0$ microns (Fig. 2).

Scleroderma bovista Fr. was found abundantly in 1962 (Mary Eriksson, TUR).

\section{LITERATURE CITED}

Andersson, O., 1950: Larger Fungi on sandy grass heaths and sand dunes in Scandinavia. Bot. Notiser 1950, suppl. 2:2.

Eckblad, F.-E., 1955: The gasteromycetes of Norway. - Nytt magasin for Bot. 4.

Eklund, O., 1944: Weitere Beiträge zur Pilzflora des Schärenarchipels Sw-Finnlands - Memor. Soc. F. Fl. Fenn. 19.

Kühner, R and H. Romagnesi, 1953: Flore analytique des champignons supérieurs. Paris.

Lange, J. E. 1938: Flora agaricina danica III. Copenhagen.

Lange, M., 1955: Macromycetes, II, Greenlands Agaricales. - Meddel. om Grønland $147: 11$.
Lemberg, B., 1934: Über die Vegetation der Flugsandgebiete an den Küsten Finnlands. Acta Bot. Fenn. 12.

Nannfeldt, J. A., 1943: The Geoglossaceae of Sweden. -Ark. f. Bot. 30:A, 4.

Rautavaara, T., 1953: Juuritryffeli (Scleroderma bovista Fr.) lentohiekassa Pohjois-Suomessa. - Karstenia 2.

Thesleff, A., 1919: Studier över basidsvampfloran i sydöstra Finland med hänsyn till des sammansättning, fysiognomi, fenologi och ekologi. - Bidr. till känned. om Finlands natur och folk $79: 1$ 